\title{
Consumption of Euterpe edulis fruit by wildlife: implications for conservation and management of the Southern Brazilian Atlantic Forest
}

\author{
JULIANO Z. DA SILVA and MAURÍCIO S. DOS REIS \\ Universidade Federal de Santa Catarina, Centro de Ciências Agrárias, Departamento de Fitotecnia, \\ Rodovia Admar Gonzaga, 1346, Itacorubi, 88034-001 Florianópolis, SC, Brazil \\ Manuscript received on May 29, 2018; accepted for publication on July 16, 2018
}

\begin{abstract}
How to cite: SILVA JZ AND REIS MS. 2019. Consumption of Euterpe edulis fruit by wildlife: implications for conservation and management of the Southern Brazilian Atlantic Forest. An Acad Bras Cienc 91: e20180537. DOI 10.1590/0001-3765201920180537.
\end{abstract}

\begin{abstract}
This study aimed to measure the wildlife consumption of Euterpe edulis fruit and use this data to discuss management possibilities. To estimate infructescence fruit volume consumed, collectors were installed in fruit-bearing palms. To characterize consumption from the ground, samples were placed next to fruiting palms. To identify wildlife and their activities, camera traps were installed in infructescences and on the ground. The results suggested that there was a small fruit surplus $(1.8 \%)$, and this finding indicated the possibility of a harvest to reduce food for the wildlife. However, recurrent variations in the annual fruit production (21.4\%) were also noted, and suggested that wildlife could tolerate some fruit harvesting. Thus, a harvest could be restricted to fruit volume that exceeds the annual average ( $94 \mathrm{~kg} / \mathrm{ha} / \mathrm{year}$ ). Turdus flavipes, a migratory bird, was the most active species in the dispersal of seeds; this finding indicates the need for broader conservation strategies. Wildlife composition also changed along with the fruiting, and this alteration suggests that dependence on the fruit is variable among different species. Seed germination and seedling mortality were high, results that indicate that local conditions may have a predominant effect on seed volume in natural regeneration density.
\end{abstract}

Key words: natural regeneration, non-timber forest products, rain forest, seed dispersal, seed predation.

\section{INTRODUCTION}

Many palms produce fruit of great economic importance. In South America, Bernal et al. (2011) described the human use of 96 palm species, of which the major producers of fruit are: Bactris gasipaes, Mauritia flexuosa, Oenocarpus bataua, Euterpe oleracea, Euterpe precatoria, Astrocaryum aculeatum, Acrocomia aculeata, Aiphanes horrida, and Bactris guineensis. Palm

Correspondence to: Juliano Zagos da Silva

E-mail: jzagos@yahoo.com.br

ORCid: http://orcid.org/0000-0001-6296-0814 and fig trees are commonly cited as key tropical species and are hyperdominant as food sources for wildlife (Terborgh 1986, Lambert and Marshall 1991, Kinnaird 1992, Peres 1994, Fredericksen et al. 1999, Galetti et al. 1999, Genini et al. 2009, Staggemeier et al. 2017). However, competition between humans and animals for these resources, coupled with an actual reduction in the resources caused by deforestation and forest fragmentation, is a growing reality, especially in the Brazilian Atlantic Forest, the primary location of Euterpe edulis. 
In many cases, reduction and change in wildlife composition have been related to reduced availability of fruit within forests (Kinnaird 1992, Galetti and Aleixo 1998, Moegenburg and Levey 2002, 2003, Weterings et al. 2008, Bicknell and Peres 2010, Galetti et al. 2013), particularly if coupled with destructive extractive methods, such as cutting plants to collect fruit (Bernal et al. 2011). Additionally, studies related to the sustainable management of non-timber forest products (NTFPs) are fundamentally concerned with natural regeneration and demographic growth of the target species (Pinard and Putz 1992, Godoy and Bawa 1993, Silva Matos et al. 1999, Reis et al. 2000, Freckleton et al. 2003, Portela et al. 2010, Pandey and Shackleton 2012), as well as the maintenance of genetic diversity (Reis 1996, Conte et al. 2003, Seoane et al. 2005, Silva and Reis 2010). Only a few studies, such as Fredericksen et al. (1999), concern the availability of resources for wildlife. The sustainability perspective normally places wildlife needs in second place, especially when it concerns the consumption of fruit pulp without seed destruction. Due to experimental difficulties, or simply because of the intrinsic idea that animals may collect and consume other resources, the proportion of fruit from a given species that should remain in the forest to feed wildlife has been ignored. However, the question, "What are the consequences of disregarding or ignoring the fruiting of species considered key in the forest environment?", is of great importance, especially when a specific fruiting period is related to a period of resource scarcity.

E. edulis has been the main producer of heart of palm in the Brazilian Atlantic Forest since the 1960s when it became the target of intensive commercial exploitation (Reis and Reis 2000). Aside from serving as raw material for the production of heart of palm, the fruit from this species is currently used in Southern and Southeastern Brazil as an alternative to açaí (Euterpe oleracea and Euterpe precatoria) (Barroso et al. 2010, Favreto et al. 2010, Trevisan et al. 2015); the pulp (exocarp and mesocarp) is extracted as a high-energy food.

$E$. edulis fruit extraction has not been intensively exploited and is a less aggressive and more sustainable possibility, since extraction does not require removing the individual palm from the forest. In addition, economic value, market acceptance, and consumer demand for this product have all increased significantly in Southern Brazil (Trevisan et al. 2015). Thus, interest in developing research and standards to support this new supply chain has grown on the part of both farmers and government agencies (Barroso et al. 2010, Favreto et al. 2010, Justen et al. 2012, Trevisan et al. 2015). On the other hand, the fruit from this palm, especially when mature, are an important food for wildlife, and its supply usually occurs between 4 and 6 months of the year (Mantovani and Morellato 2000, Galetti et al. 1999, Genini et al. 2009, Staggemeier et al. 2017, Silva and Reis 2018). A total of 58 bird and 21 mammal species are known to use this resource, and some of these species are considered endangered (Galetti and Chivers 1995, Galetti and Aleixo 1998, Galetti et al. 2000, 2001, Reis and Kageyama 2000, Mikich 2002, Pizo et al. 2002, Galetti et al. 2013). Thus, E. edulis is considered a hyperdominant and keystone species within the Atlantic Forest ecosystem (Galetti and Chivers 1995, Galetti et al. 2000, 2001, Mikich 2002, Pizo et al. 2002, Staggemeier et al. 2017).

Studies on E. edulis include: Galetti and Chivers (1995), Reis (1996), Galetti and Aleixo (1998), Conte et al. (2000), Galetti et al. (2000), Mantovani and Morellato (2000), Reis and Kageyama (2000), Freckleton et al. (2003), Fantini and Guries (2007), Genini et al. (2009), Barroso et al. (2010), Favreto et al. (2010), Portela et al. (2010), Silva and Reis (2010), and Paludo et al. (2012). These authors have reported on fruit production, consumption, and extraction, but have neglected fruit consumption by wildlife, 
especially from the perspective of supporting sustainable extraction of the fruit. Such studies are generally directed toward the behavior of wildlife, the dynamics of regeneration, or reproductive phenology and maintenance of genetic diversity. Thus, this paper aims to broaden the study of $E$. edulis by examining fruit consumption by wildlife, and looks to establish quantifiable surpluses by identifying the percentage of fruit consumed and the percentage of seeds that remain viable for germination. We hypothesize that such surpluses can serve as the basis for sustainable management strategies and thereby maintain interactions with wildlife and natural regeneration dynamics.

\section{MATERIALS AND METHODS}

\section{STUDY AREA}

The study site was located in the Ibirama National Forest (Ibirama FLONA), Santa Catarina, Brazil. This area contains 463 ha of native forest that is connected to other larger forest fragments (http:// www4. icmbio.gov.br/flonaibirama). The local vegetation is composed of montane Atlantic rainforest (Klein et al. 1986) and exhibits structural characteristics similar to areas of primary forest cover.

\section{QUANTIFICATION OF FRUIT PRODUCTION}

To characterize reproductive palm density, the number of seedlings in class I (with height of insertion of the youngest leaf less than $10 \mathrm{~cm}$ ), and fruit production per area, data were obtained from 24 existing permanent plots $(40 \times 40 \mathrm{~m})$ (Conte et al. 2000) for which a phenological assessment was carried out for all E. edulis individuals (888 reproductive palms) during the 2 years of evaluation (2008 and 2009). In order to characterize annual variation in the number of reproductive palms, plants that emitted inflorescences were recorded in these same plots for 11 fruiting seasons (2004 to 2009, 2011, and 2013 to 2016).
FRUIT AND SEED USE, AND GERMINATION PERCENTAGE

To quantify fruit use in infructescences and the number of viable seeds for germination, 114 collectors (Supplementary Material, Figure S1a) were installed, one for each palm infructescence on 92 reproductive palms. This installation allowed us to identify and quantify predation, transport, and pulping.

After all fruit was counted on each infructescence, the collectors were installed below fruit bunches by fixing them on the stipe of palms (Figure S1a). Each collector consisted of an iron ring with a $3 \mathrm{~m}$ circumference and a sewn funnelshaped screen net. Of the 114 collectors, 80 were positioned in 2008 and 34 in 2009 in order to sample different reproductive cycles.

All fallen fruit in the collectors were visually assessed and quantified for signs of predation (seed damage due to insect drills, vertebrates, or fungi), pulping (pulp exocarp and mesocarp removal without damage to the seed), cracks (pulp and endosperm cracks through seed growth), dryness (endosperm was absent and no exocarp damages), scratches (marks of nails, beaks, or teeth, but without pulping or predation; these observations characterize fruit loss during feeding), or whether it remained intact. During each evaluation of the fallen fruit in the collectors, 20 fruit per infructescence were randomly sampled and cut. This assessment aimed to identify the presence of seed damage that was not externally perceptible (caused by insects or fungi) and to correct the number of intact fruit in each evaluation.

Fruit that did not fall into the collectors were considered dispersed or transported primarily by wildlife. This conclusion was based on results obtained with the installation of camera traps, as described below. The volume of primary seed dispersal was corrected using the percentage of predation observed in the infructescences. 
The percentage of pulped fruit (dispersers are regurgitants or seed defecators; see Galetti et al. 2013) was also corrected for the rates of predation, rot (when it was not possible to identify the agent; most likely fungi or bacteria), secondary transport, and any intact remnants, as observed in seed samples arranged on the soil (609 samples from 50,065 total seeds).

To study the activities of wildlife toward fruit on the ground, samples of unripe (47 samples from 2,551 total fruit), ripe (251 samples from 11,244 total fruit), dried (346 samples from 9,269 total fruit), and pulped fruit (609 samples from 50,065 total seeds) were placed on the ground below collectors for each reproductive palm and evaluated during 2008 and 2009. The samples were placed in defined spaces where fruit were separated by type. Evaluation and replacement of fruit were performed weekly, and the intensity was determined by the amount of fruit that fell into the collectors. In these samples, fruit and seeds were also evaluated for pulping, transport, predation, decay, percent that remained intact, and seedling mortality that originated from seed germination. Due to fruit or seed replacement on soil samples, the germination percentage was evaluated in a greenhouse. Thus, we used 8,222 seeds pulped by animals from 67 palm with installed collectors.

When fruit or seeds disappeared from soil samples, these were considered to be secondary dispersal or transport activities, and these volumes were later corrected for percentages of predation, rot, and quantity that remained intact. Corrections in these cases depended on the object of study. Thus, for seeds, only one correction was performed, using data from seed samples arranged on the soil (609 samples from 50,065 total seeds); two corrections were required for fruit: one based on samples of fruit arranged on the soil (251 samples from 11,244 total fruit) and another based on seeds (609 samples from 50,065 total seeds). Double correction of the fruit transported at soil level was performed based on the continuity of wildlife activities on the volume of pulped fruit, which behave like seeds when pulp is lost. Between 2013 and 2014, camera traps were also installed to monitor seeds and fruit arranged at ground level, as described below.

\section{CHARACTERIZATION OF WILDLIFE SPECIES AND THEIR ACTIVITIES}

We installed camera traps to identify wildlife species and their interaction frequencies, and quantify the number of fruit and seeds dispersed, predated, pulped, and regurgitated or defecated (for seeds) in infructescences or at the base of the reproductive palms. Monitoring was performed monthly, including periods of 15 to 20 days per month per trap where images were recorded day and night $(24 \mathrm{~h})$ throughout the entire fruiting period that occurred in 2013 (7 months) and during 4 months of fruiting that occurred in 2014. The camera configuration used was: high sensitivity to movement, videos up to $1 \mathrm{~min}$, and 2 min interval between recordings.

Up to 11 camera traps per month were installed to monitor infructescences of 64 reproductive palms: 34 in 2013 and 30 in 2014 (the same plants where the collectors were installed). Trap installation was either directly among the leaf sheaths of the fruiting plant (Fig. S1b) or indirectly on the stipe of nearby plants and not more than $2 \mathrm{~m}$ away from the monitored infructescence (Fig. S1c).

To monitor fruit and seeds arranged on the soil, up to 6 camera traps per month and samples with fruit and seeds (with monthly replenishment) were used. The samples were kept separate and distant at a maximum of $1.5 \mathrm{~m}$ from the traps. Traps were installed on the same plants where the collectors were mounted. They were fixed at $50 \mathrm{~cm}$ in height on 30 fruiting palms (Fig. S1d): 19 in 2013 and 11 in 2014.

The study area was also evaluated for the average size of seeds regurgitated by frugivores and the richness of birds classified as follows: frugivory 
score $=1$ : sporadic, 2 : moderate, and 3: extensive frugivory; feeding behavior: R: regurgitate seeds, D: defecate seeds, SP: seed predator, and PC: pulp consumer; classification follows the method proposed by Galetti et al. (2013). The objective of this procedure was to compare the study area with areas considered defaunate and non-defaunate as studied by Galetti et al. (2013). The regurgitated seeds were collected during fruiting from 2013 to 2017, with a minimum distance of $15 \mathrm{~m}$ between seeds. A total of 3,772 seeds were measured in three axes. We used the smallest measure obtained for each seed for comparisons with the populations studied by Galetti et al. (2013).

\section{TESTING AND ANALYSIS}

The comparisons between densities of palms in fruiting, number of reproductive structures emitted by reproductive palms, number of fruit formed per infructescence, kilograms fruit produced per hectare (ha), average seed size, bird richness, wildlife actions (percentage of pulp, predation, dispersion, etc.), and percentages of seed germination and seedling mortality, were tested using $95 \%$ confidence intervals (CIs; t distribution). Comparisons between monthly frequencies of species and wildlife families were tested by $95 \%$ CIs, which were obtained by resampling $(1,000$ bootstraps) using $\mathrm{R}$ software ( $\mathrm{R}$ Development Core Team 2015). The relationships between the monthly frequencies of the wildlife families and the percentages of fruit transport, pulping, and intact fallen fruit were calculated using the Pearson correlation, and statistical significance $(95 \%)$ was determined using the $t$ test $\left(t=r / \sqrt{ }\left(\left(1-r^{2}\right) /(n-2)\right)\right.$.

\section{RESULTS AND DISCUSSION}

\section{QUANTIFICATION OF FRUIT PRODUCTION}

The study area had an average density of $231 \pm 33$ reproductive palms/ha; however, not all individuals reproduced annually. In the 2008 fruiting season,
$228 \pm 33$ palms/ha produced infructescences, while in 2009 , only $133 \pm 36 \mathrm{palms} /$ ha produced infructescences. Considering the 11 recorded fruiting seasons, the average number of palms in reproduction per ha/year was $173 \pm 37$, with a minimum value of $75 \mathrm{palms} / \mathrm{ha} / \mathrm{year}$ in 2005 and a maximum value of $266 \mathrm{palms} / \mathrm{ha} / \mathrm{year}$ in 2015 . Annual variations in the density of reproductive palms were also observed by Mantovani and Morellato (2000), who registered variations between 60 and 109 palms/ha.

Annual variations were observed in the number of infructescences with ripe fruit per plant. In 2008, considering only the reproductive palms, the average number of ripe infructescences per plant was $1.47 \pm$ 0.08 , and in 2009, $0.86 \pm 0.05$ ripe infructescences were registered per plant. These values were similar to those observed by Silva Matos and Watkinson (1998) and Mantovani and Morelatto (2000), with variation between $0.63-1.8$ infructescences/plant; these authors did not distinguish between unripe and ripe infructescences.

The number of ripe fruit produced per infructescence also varied between years. In 2009, despite a lower reproductive palm density, 2,789 \pm 455 ripe fruit were registered per infructescence. This number was higher than the observed value for 2008 of $1,785 \pm 220$ fruit/infructescence. These variations resulted in an annual production that ranged from 599,310 fruit/ha/year in 2008 to $318,046 \mathrm{fruit} / \mathrm{ha} / \mathrm{year}$ in 2009 , or 1,031 and $547 \mathrm{~kg} / \mathrm{ha} /$ year, respectively, (average $790 \mathrm{~kg} /$ ha/year) when considering that each fruit weighs approximately $1.72 \mathrm{~g}$ (Fleig and Rigo 1998).

The average number of fruit produced per infructescence, as observed in other studies, was quite variable (from 873 to 3,365 fruit/ infructescence; Silva Matos and Watkinson 1998, Mantovani and Morellato 2000, Calvi and PiñaRodrigues 2005). This variation resulted mainly from the different methodologies applied in the estimates and makes comparisons with these 
studies of questionable value. However, based on the number of reproducing plants in the 11 fruiting seasons recorded in the present study, we estimated production variation using the average number of ripe infructescences emitted per reproductive palm (1.17) and the average number of fruit formed by infructescences $(2,175)$ observed in 2008 and 2009. These estimates resulted in an average production of $759 \pm 162 \mathrm{~kg} / \mathrm{ha} /$ year, with a minimum production of $330 \mathrm{~kg} / \mathrm{ha} /$ year registered in 2005 and a maximum production of $1,163 \mathrm{~kg} /$ ha/year registered in 2015 . It should be noted that the confidence interval obtained $(162 \mathrm{~kg} / \mathrm{ha} /$ year), represented $21.4 \%$ of the average annual production (equivalent to the production of 37 palms). This finding indicates that the wildlife is naturally adapted to this fruiting oscillation.

IDENTIFICATION OF WILDLIFE AND

QUANTIFICATION OF THEIR ACTIVITIES

Fifty-nine vertebrate species that interacted with $E$. edulis fruit and seeds (Campos et al. 2012, Galetti et al. 2013) were recorded in Ibirama National Forest (Table SI). However, only 31 species consumed $E$. edulis fruit and seeds in the study area (Tables I, II and SI). This number surpassed other studies, even when considering the richness of birds alone (28 species; Silva Matos and Watkinson 1998, Galetti et al. 1999, Fadini and Marco Jr 2004, Cerisola et al. 2007, Fadini et al. 2009, Campos et al. 2012, Omote et al. 2014, Cazassa et al. 2016, Silva et al. 2017). The richness of frugivorous birds (Table SI - total: 43 , sporadic: 7 , moderate: 6 , extensive frugivory: 6; regurgitate seeds: 19 , defecate seeds: 3, seed predators: 7, and pulp consumers: 14) and the average size of seeds regurgitated by these birds $(11.49 \pm 0.9 \mathrm{~mm})$ allowed us to classify the FLONA de Ibirama as among the best areas considered as non-defaunated (total richness: $36 \pm 4.5$, sporadic: $5.9 \pm 0.9$, moderate: $6.3 \pm 0.5$, extensive frugivory: $5.1 \pm 1.1$; regurgitate seeds: $17.3 \pm 1.9$, defecate seeds: $1.5 \pm 0.4$, seed predators: $3.5 \pm 0.9$, and pulp consumers: $13.7 \pm 1.8$; seed size: $11.39 \pm 0.4 \mathrm{~mm}$ ) as described by Galetti et al. (2013).

In ripe infructescences, 6,956 interactions were observed over 1,551 monitoring days. These observations resulted in the identification of 24 species (Table I), mostly birds (23), results similar to observations in other studies (Galetti et al. 1999, 2013, Silva et al. 2017). Monitoring of unripe infructescences did not result in any interactions despite including 9 palms and 126 monitoring days. This finding indicated little interest among vertebrates, a fact also suggested by the results of installed collectors, as described below.

Of the total fruit used by vertebrates in the infructescences, $30.4 \%$ were pulped or regurgitated, $62.6 \%$ were dispersed, and $6.9 \%$ were knocked down during the feeding attempt (Table I). The Turdidae family was most frequently observed in infructescences (49.8\%; Table I), and also represented the greatest fruit user $(43.3 \%)$, observations similar to other studies (Silva Mattos and Watkinson 1998, Galetti et al. 1999, Fadini et al. 2009, Omote et al. 2014, Cazassa et al. 2016).

The main dispersers recorded were Turdus flavipes, Selenidera maculirostris, and Turdus albicollis. Together, these species accounted for $87.6 \%$ of primary dispersal (Table I). The predominance of regurgitated seeds (97\%) surpassed that of defecated seeds $(2.1 \%$; by the Cracidae family), and favors a higher percentage of germination (Leite et al. 2012). Among the dispersers, T. flavipes accounted for more than one quarter of fruit consumed by vertebrates in the infructescences and $41.7 \%$ of primary dispersal (Table I). This species was also reported as among the most frequent visitors in other studies (Galetti et al. 1999, Cerisola et al. 2007, Fadini et al. 2009, Castro et al. 2012, Omote et al. 2014, Cazassa et al. 2016). The importance of T. flavipes and its migratory behavior suggest that E. edulis conservation needs to extend over a regional and not just local population level. 


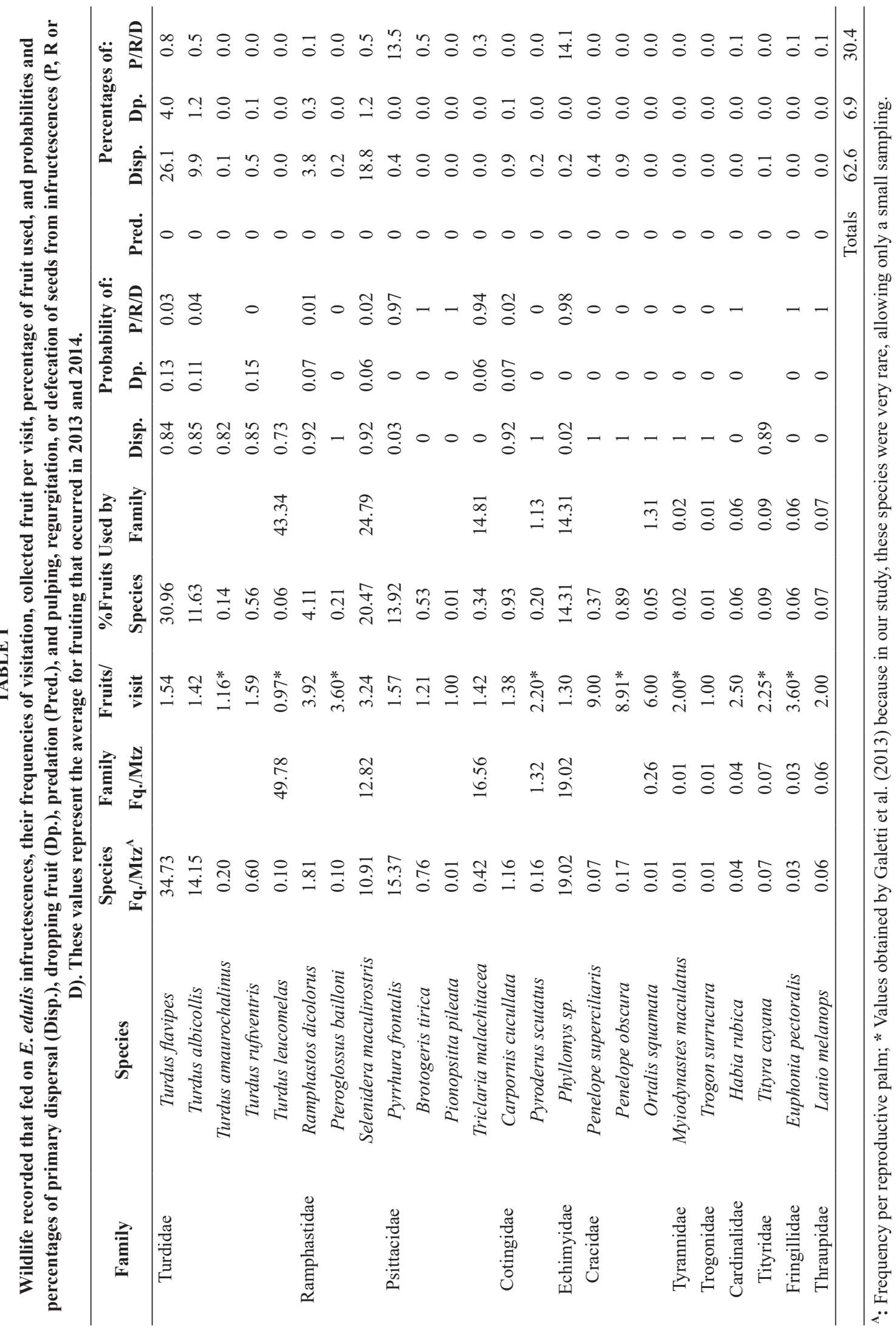




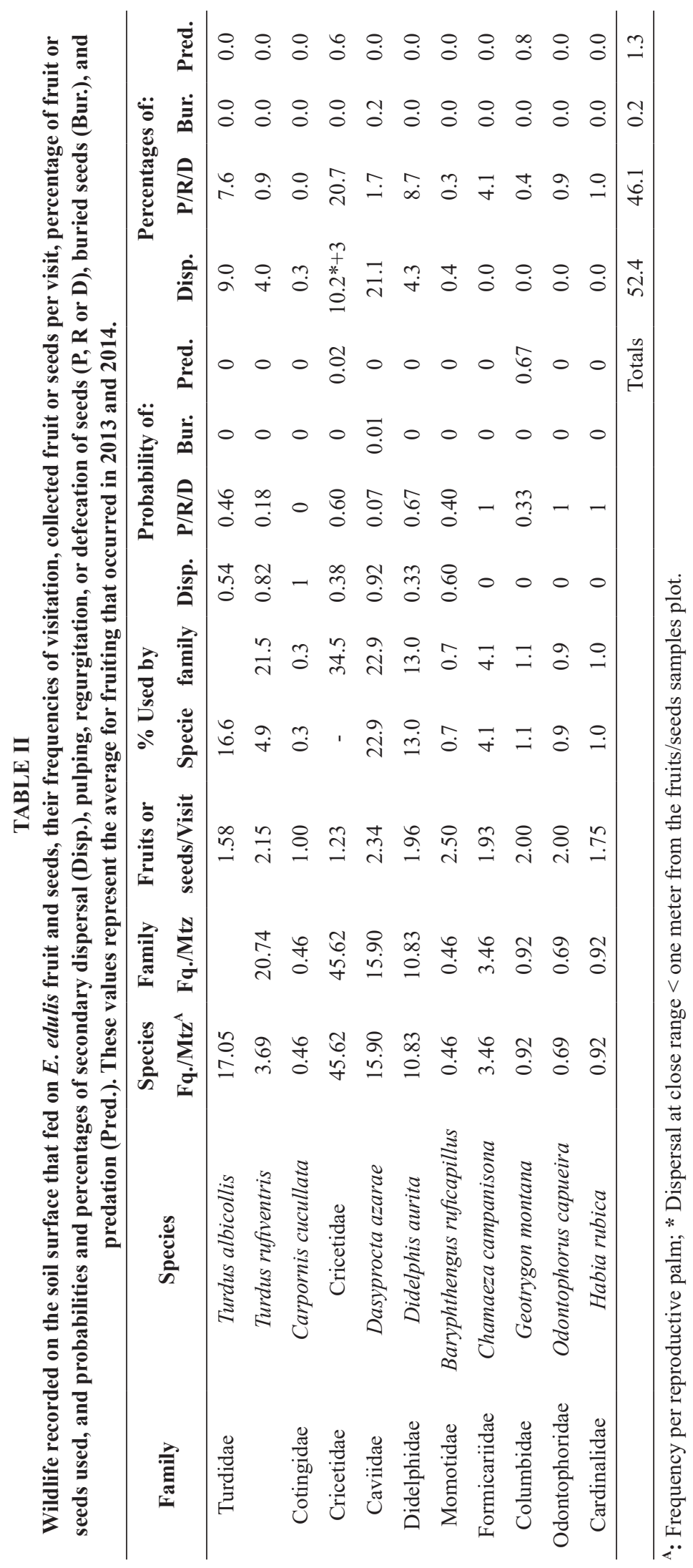


The main fruit pulpers in infructescences belonged to the Psittacidae family; they were responsible for $47.1 \%$ of pulped fruit. When considering seed predators (Galetti et al. 2013), it should be emphasized that they act only as pulp consumers, i.e., species that predominantly remove fruit pulp without carrying out the dispersal or predation of the seeds, behavior already observed by Laps R.R. (unpublished data).

Monitoring of vertebrate activities on E. edulis fruit and seeds arranged at ground level totaled 434 records during 813 days of monitoring. Interactions with at least 11 species were observed (Table II), since rodents of Cricetidae were not identified. These records characterized activities initiated mainly on ripe fruit (430 records) and demonstrated the relatively small interest of vertebrates in seeds. Seeds were predominantly reserved for rodents of the family Cricetidae and Geotrygon montana (Columbidae) that predated $1.3 \%$ of the amount of fruit and seeds used by vertebrates at ground level.

Contrary to what was observed in infructescences, mammals were the predominant actors on the soil with respect to frequency of interactions $(72.4 \%)$ and percentage of fruit used (70.5\%). Here, we highlight the activities of rodents of the Cricetidae and Caviidae families that together used more than half of the available fruit (Table II).

Vertebrate activities relative to fruit and seeds arranged on the soil were predominantly involved in secondary dispersal (52.4\%) and pulp (46.1\%; Table II). However, dispersal was of a low quality, generally related to the pulp at distances of less than $1 \mathrm{~m}$ from the samples (54.2\%). Greater distances were only reached by seed-regurgitating birds (T. albicollis, T. rufiventris, Carpornis cucullata, and Baryphthengus ruficapillus) and by rodents of the Cricetidae family, which presented a low probability of seed predation ( $2 \%$; Table II).

\section{USE OF FRUIT IN INFRUCTESCENCES}

Through an analysis of fallen fruit in collectors (Table III; Figure 1), we observed that an average of $76.5 \%$ of fruit were used directly from infructescences $(39.4 \%$ transported, $25 \%$ pulped, $0.5 \%$ predated, $1.9 \%$ insect drills, $6.9 \%$ fungi, $2.8 \%$ scratched or caught and lost). Contrary to expectations, a very similar proportion of total available fruit was utilized in 2008 and 2009, 77.9 $\pm 3.4 \%$ and $73.3 \pm 9 \%$, respectively, even when the amount of ripe fruit produced in 2009 was $47 \%$ lower than that observed in 2008.

Discounting the percentage destroyed by insects and fungi ( $8.8 \%$; Table III), since they could not be recorded by the camera traps, and correcting the proportion of the fruit with the new total $(67.7 \%)$, which expresses vertebrate activity, we calculated the following proportions: transported: $58.2 \%$, pulped: $36.9 \%$, predated: $0.7 \%$, and scratched: $4.1 \%$. These results were generally congruent with those of the estimated percentages through the installation of the camera traps (transported: 62.6 $\%$, pulped: $30.4 \%$, predated: $0 \%$, and scratched: $6.9 \%$; Table I), and these findings suggest small variations between the fruiting seasons (collectors considered the average of 2008 and 2009, while camera traps considered the average of 2013 and 2014).

As shown in Table III, the percentage of fruit with fungi and intact fruit tend to decrease, while the percentage of transported fruit increased between May and July. These results may be associated with the onset of austral winter. During winter, the region is drier than summer, which could contribute to a reduction in fungal attacks. The changes in percentages of intact and dispersed fruit (Table III) were related to changes in the composition of the wildlife (Figure 2a). Seed dispersers (mainly Turdidae and Ramphastidae) predominated until July, accounting for $84.7 \%$ (CI: $78.3-90.6 \%$ ) of the interactions (non-dispersers: $15.3 \%, \mathrm{CI}: 9.3$ - 


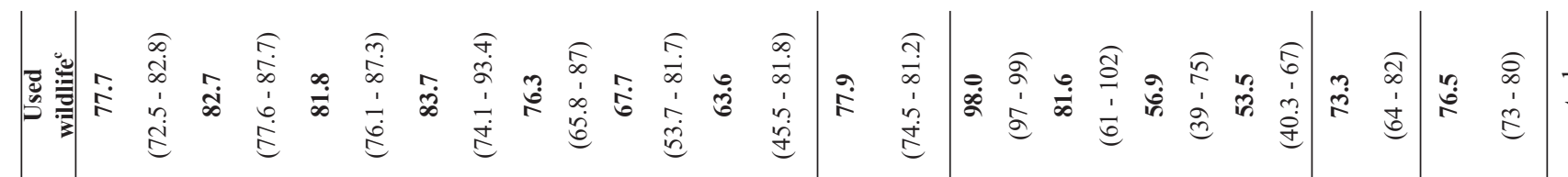

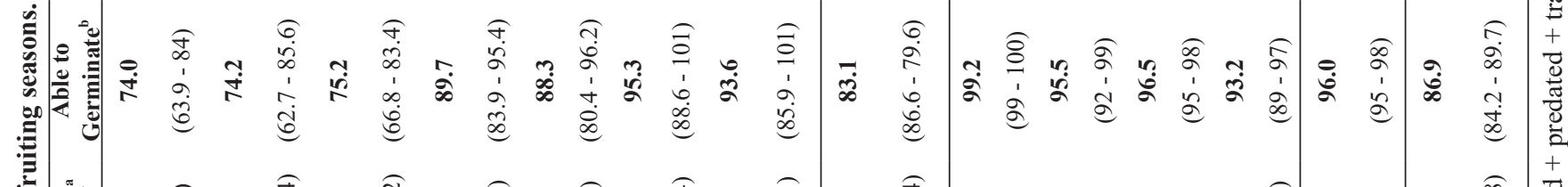

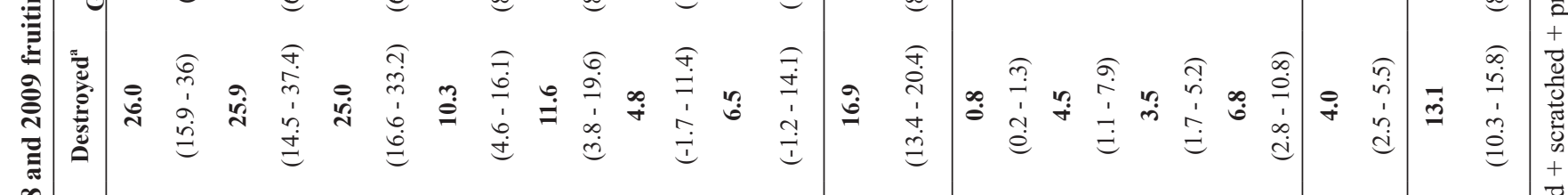

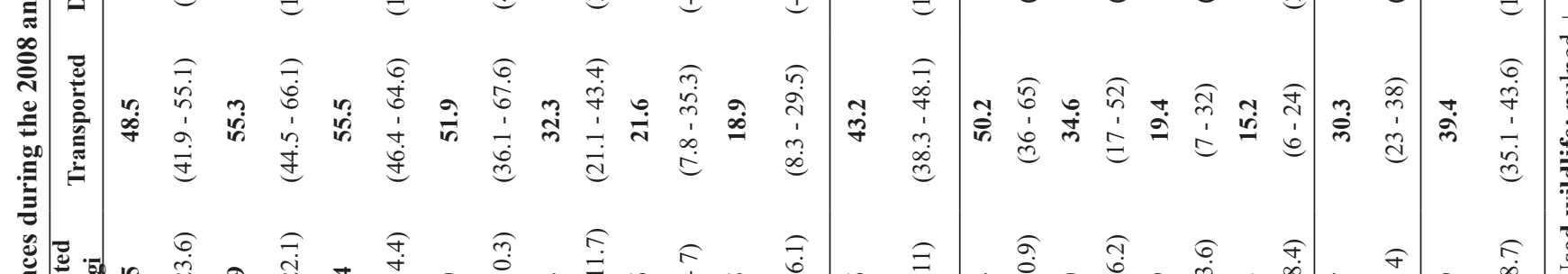

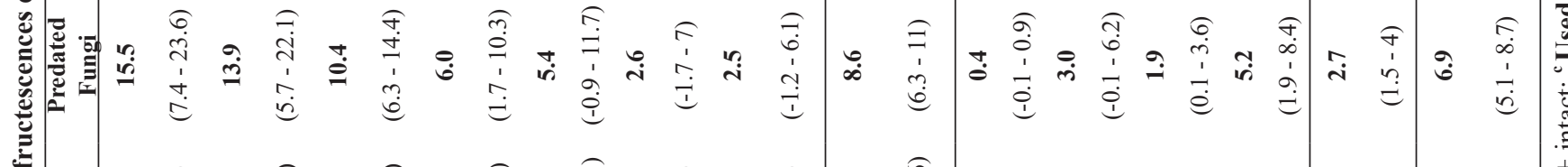

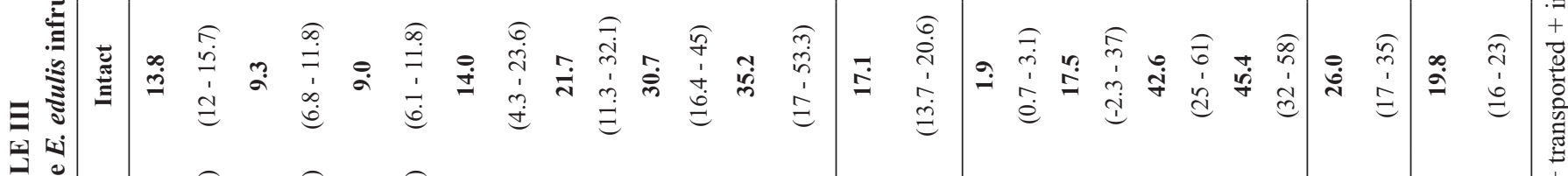

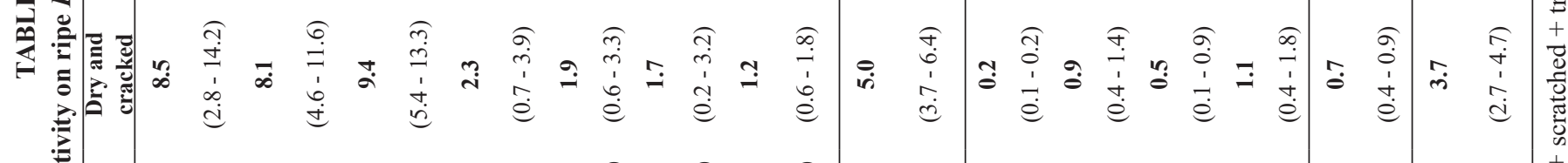

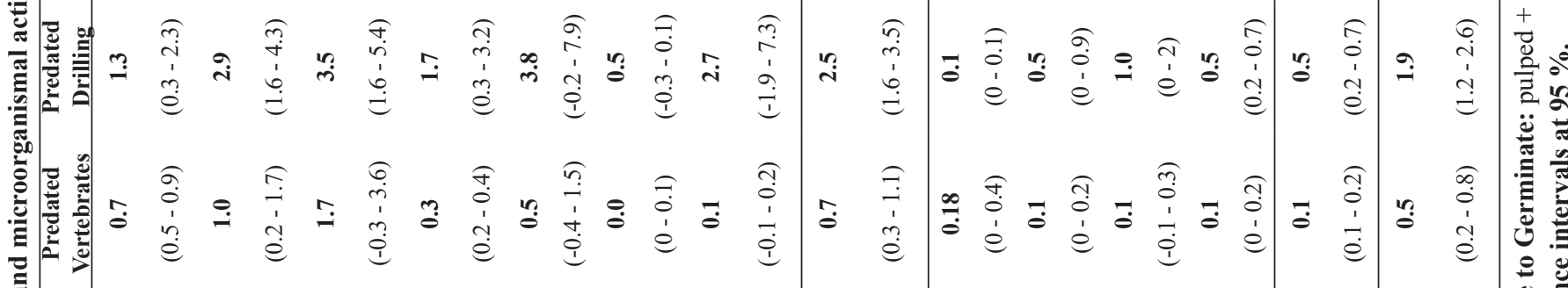

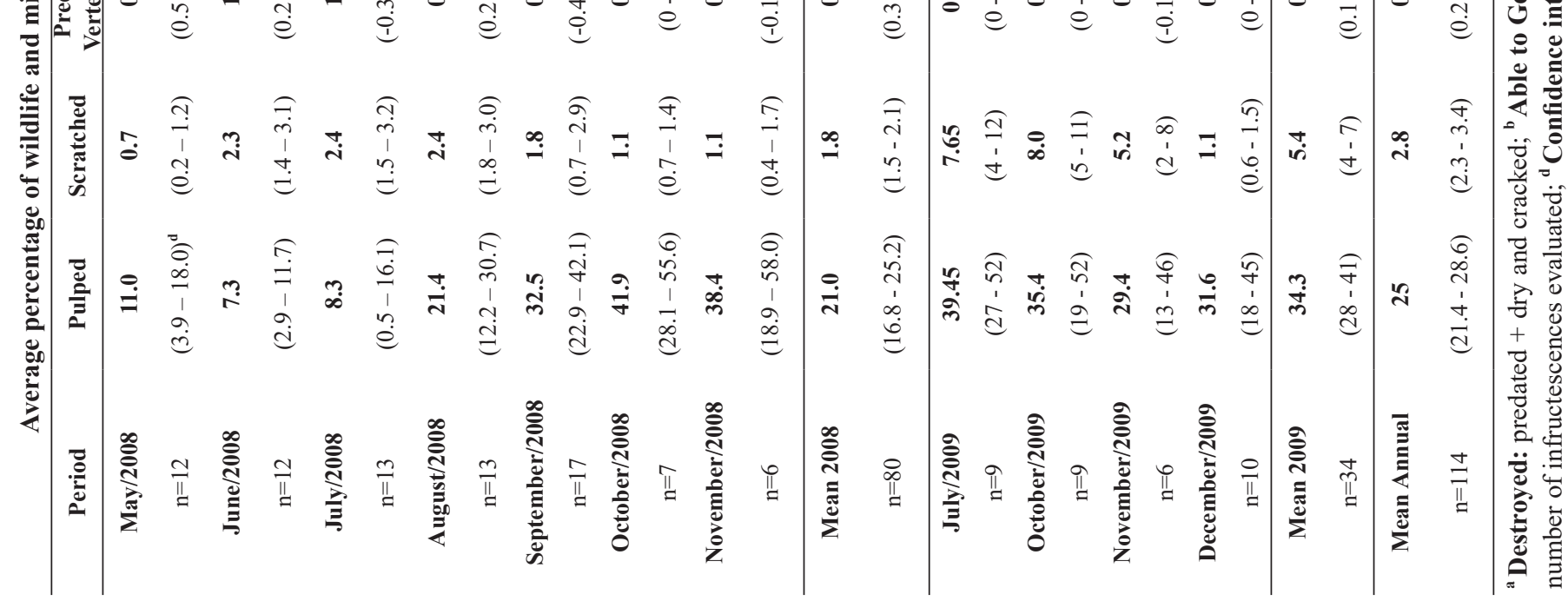




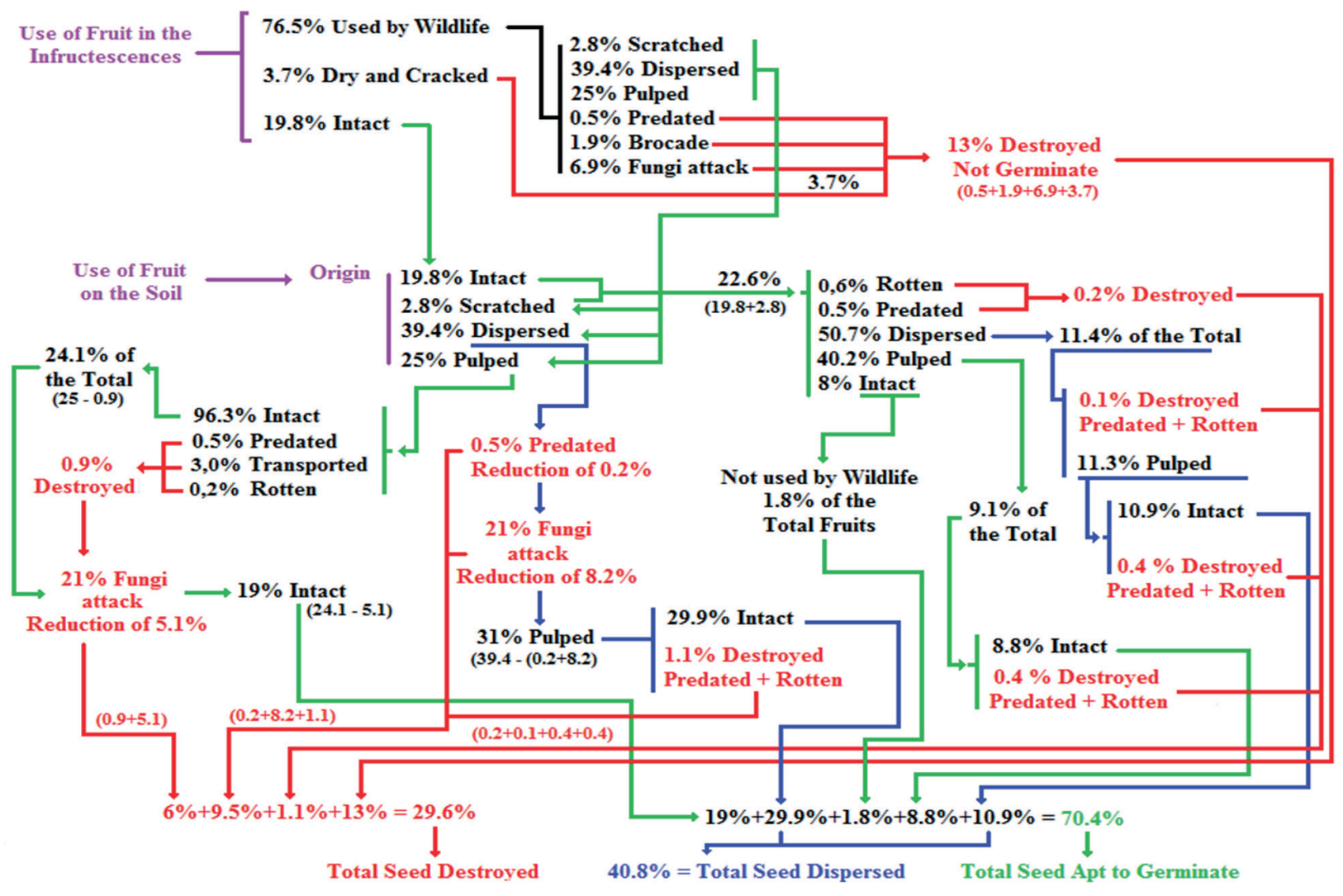

Figure 1 - A schematic overview of the wildlife and microorganismal activities that occurred during E. edulis fruiting (from 114 infructescences and 1,253 samples of unripe, ripe, dried, and pulped fruit placed on the ground, with 73,129 fruit per seed).

$21.7 \%$ ). From August onwards, pulp consumers, mainly Psittacidae and Echimyidae, predominated and reached $62.9 \%$ (CI: $52.5-72.1 \%$ ) of the interactions (dispersers: $37.1 \%$, CI: $27.8-47.3$ $\%$ ). This wildlife shift resulted in changes in the monthly percentages of transported, pulped, and fallen intact fruit. Overall, there were high correlations between the Turdidae family and the percentages of fruit transported $(r=0.85)$ or fallen intact $(r=-0.87)$, and between the Psittacidae and Echimyidae families and the percentage of pulped fruit on the infructescences ( $r=0.88$ for both).

The largest change in wildlife composition occurred in the Turdidae family (Figure 2a), mainly represented by $T$. albicollis and T. flavipes, both of which reduced their frequencies after August (Figure 2b). Part of this reduction could be explained by the gradual migration of $T$. flavipes, which occurs during late winter and spring, when it moves from the southern mountainous regions to the north to the Espirito Santo State (Sick 1997), in addition to migrating along the altitudinal gradient following the fruiting of E. edulis (Castro et al. 2012). However, T. albicollis is a resident species, a fact that indicates that it naturally uses other resources after August, as corroborated by Castro et al. (2012), who observed that the fruiting of $E$. edulis influences the abundance and migration of $T$. flavipes, but not T. albicollis, between different altitudes and forest typologies. These data reflect concerns about fruit management between April and July in Southern Brazil, in particular with respect to the Turdidae family, its feeding habits, and population dynamics, owing to annual variations in fruit production. 

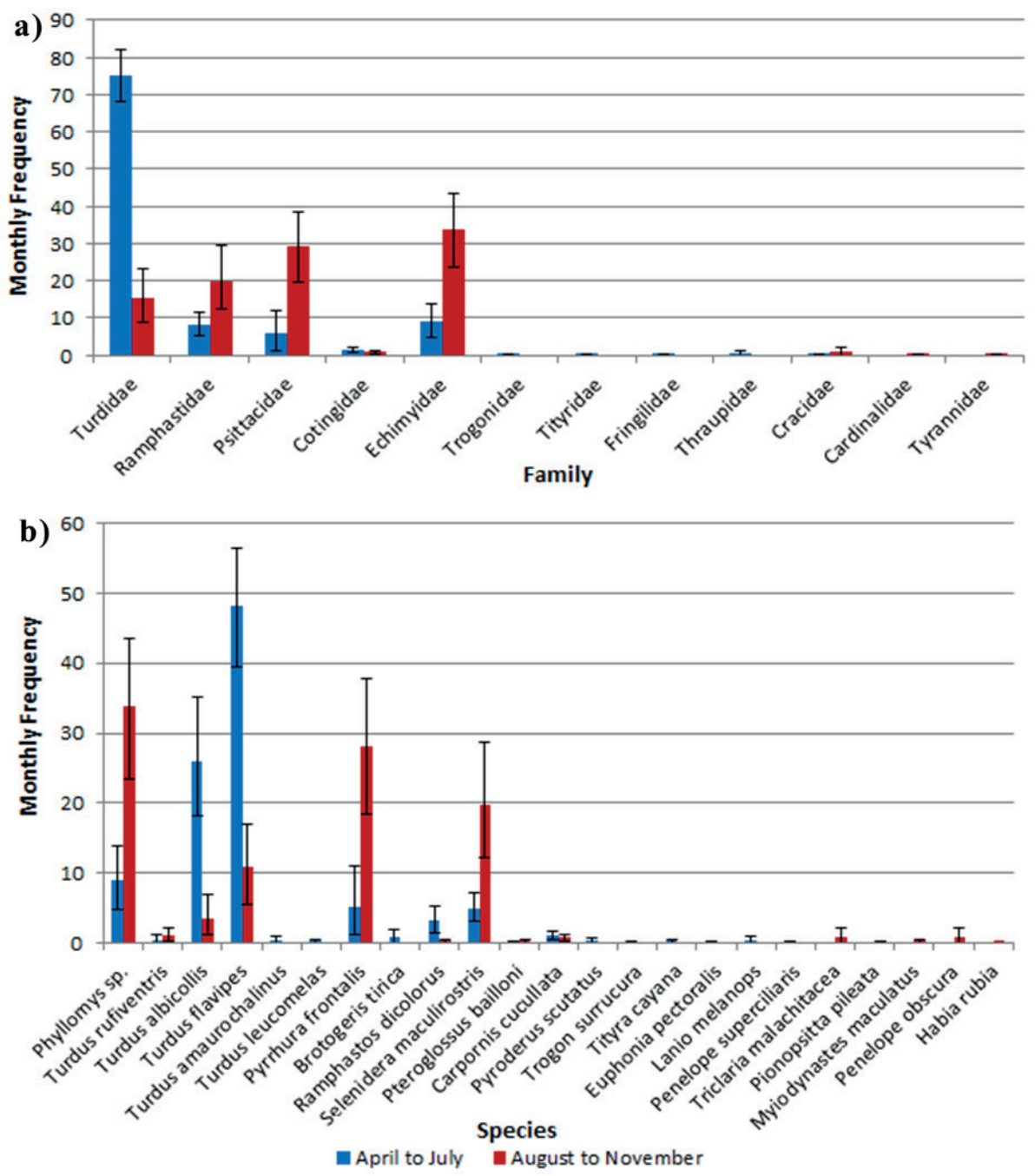

Figure 2 - Monthly average frequency of the: a) families and b) species recorded that fed on $E$. edulis infructescences during April to July and August to November during the 2013 and 2014 fruiting seasons. Confidence intervals $(95 \%)$ are indicated.

Of the total amount of fruit, only $19.8 \%$ fell to the ground intact (Table III) with no evidence of animal activity, and these fruit were also free of fungi and insect drills. This result highlights the importance of this food source for wildlife, mostly birds, that feed directly on infructescences (Table I), as discussed by Galetti et al. (2000), Reis and Kageyama (2000), and Galetti et al. (2013). It is also evident that the supply of pulp on the ground is proportionately low, corresponding to only 22.6 $\%$ of what is produced in an infructescence $(19.8$ $\%$ intact $+2.8 \%$ scratched) or only $179 \mathrm{~kg} / \mathrm{ha} /$ year, considering the average production of 2008 and 2009 (790 kg/ha/year). Therefore, the fruit is characterized as a scarcer resource on the ground and concentrated beneath reproductive palms.

For natural regeneration of the species, $86.9 \%$ of the total amount of fruit produced remained and were categorized into fruit viable for germination $\{25 \%$ pulped, $19.8 \%$ intact, $2.8 \%$ scratched, and $39.4 \%$ transported (dispersers are regurgitators and seed defecators); Figure 1\}. This represents an average of 399,050 seeds/ha. 


\section{USE OF FRUIT ON THE SOIL}

For wildlife that feed on the ground, different types of fruit are available \{unripe (green), ripe, pulped, and dry pulp\}. Only $8 \%$ of the ripe fruit was unused (Table IV; Figure 1). In contrast, unripe, pulped, and dried fruit were barely utilized by wildlife. When analyzing the percentage of pulped and transported fruit, as shown in Table IV, fruit preference was evident, since $98 \%$ of pulping and $86 \%$ of dispersing that occurred in the soil originated from ripe fruit pulp.

The behavior of wildlife on pulped fruit was very similar to that observed for unripe and dry fruit, where $96.3 \%$ of the fruit showed no animal activity (Table IV). However, pulped and unripe fruit contributed $13 \%$ to secondary dispersal, and thus represented, 5.1 and $8.2 \%$, respectively, of dispersed seeds. As the main food resource offered by pulped fruit is the seed's endosperm, the seeds would be destroyed and thus contribute very little to secondary dispersal. This supposition was corroborated by records obtained with the camera traps, which only recorded activities on seeds that resulted in predation. In addition, unripe fruit reaches the ground as immature fruit with insect drills or fungi in the endosperm.

Based on the information presented in Table $\mathrm{IV}$, the importance of ripe fruit for wildlife that feeds on the ground and for secondary dispersal is evident. Furthermore, the results obtained provide an understanding of the sensitivity of this system since the amount of ripe fruit that reached the forest floor was a relatively small proportion $(22.6 \%$ produced by an infructescence), and of these fruit only $8 \%$ were not consumed. That is, only $1.8 \%$ of ripe fruit produced were not used by animals $(14.2 \mathrm{~kg} / \mathrm{ha} /$ year or the equivalent of 3.8 ripe infructescences/ha/year).

Secondary dispersal involved the transport of $10.9 \%$ of the total produced fruit (Figure 1), and originated from the actions of wildlife on soil fruit with ripe pulp (22.6\%: $19.8 \%$ intact and 2.8 $\%$ scratched; Table III; Figure 1). The $10.9 \%$ of secondary dispersal is probably underestimated because the wildlife that feed on the ground can still move the fruit and seeds via primary dispersal. However, this percentage will not be much greater, since primary dispersal animals carry the fruit but only because of their interest in the pulp. The fruit are then likely to be discarded after being pulped. As shown in Table IV, few seeds left on the soil were dispersed by wildlife.

\section{CONSUMPTION OF FRUIT AND PERCENTAGE OF SEEDS AVAILABLE FOR NATURAL REGENERATION}

Seeds available for natural regeneration originated from $19.8 \%$ intact fruit, $25 \%$ pulped fruit, 2.8 $\%$ scratched fruit, and $39.4 \%$ dispersed fruit (a total of $87 \%$; Table III; Figure 1). However, these percentages are reduced due to ecological processes that occur on the soil, where seeds are subjected to pulping, predation, transport, and rotting caused by microorganisms. These reductions are outlined in Figure 1 and detailed in the Appendix.

Including all losses and reductions, $70.4 \%$ (19 $\%+21.5 \%+29.9 \%$ ) of seeds could germinate. Of the percentage destroyed, $13 \%$ occurred by direct wildlife activity on infructescences (Table III; Figure 1). The destruction of the remaining 16.6 $\%$ of seeds occurred mainly in the soil and during dispersal (13.3 \% with fungal attacks and 3.3\% due to predation and rot). These results are summarized in Figure 1, which shows $70.4 \%$ of seeds were capable of germination and $29.6 \%$ were destroyed (20.2 \% by fungus, $1.9 \%$ by insect larvae, $3.8 \%$ by predation and microorganisms, and $3.7 \%$ as a result of dry and cracked fruit).

The estimated percentage of seeds that could germinate $(70.4 \%)$ was very close to that observed for seeds evaluated in the greenhouse $(78.8 \pm 5.1$ $\%)$. The percentage of destroyed seeds $(21.2 \pm$ $5.1 \%$ ) was possibly related to fungal attack, since the same percentage was observed by the internal 
TABLE IV

Average percentage of wildlife and microorganismal activity on the different classes of available fruit on the soil during the 2008 and 2009 fruiting seasons.

\begin{tabular}{|c|c|c|c|c|c|c|c|c|c|c|c|}
\hline \multirow{3}{*}{$\begin{array}{c}\text { Class of } \\
\text { Fruit }\end{array}$} & \multicolumn{11}{|c|}{ Wildlife and/or microorganism actions } \\
\hline & \multicolumn{2}{|c|}{ Intact } & \multicolumn{2}{|c|}{ Pulped } & \multicolumn{2}{|c|}{ Predated } & \multirow{2}{*}{$\begin{array}{l}\text { Pred. dril. } \\
\quad \% \mathrm{CF}\end{array}$} & \multicolumn{2}{|c|}{ Transported } & \multicolumn{2}{|c|}{ Rotten } \\
\hline & $\% \mathrm{CF}^{\mathrm{a}}$ & $\% \mathrm{CA}^{\mathrm{b}}$ & $\% \mathrm{CF}$ & $\% \mathrm{CA}$ & $\% \mathrm{CF}$ & $\% \mathrm{CA}$ & & $\% \mathrm{CF}$ & $\% \mathrm{CA}$ & $\% \mathrm{CF}$ & $\% \mathrm{CA}$ \\
\hline Dry pulp ${ }^{c}$ & 83.3 & 29.7 & 0.4 & 1.0 & 0.4 & 17.4 & 0 & 0.3 & 0.5 & 15.6 & 92.3 \\
\hline $\mathrm{CI}( \pm)$ & 12,9 & & 0.5 & & 0.5 & & 0 & 0.2 & & 12.7 & \\
\hline Green fruits ${ }^{\mathrm{d}}$ & 93.0 & 33.1 & 0.6 & 1.5 & 0.9 & 39.1 & 0.2 & 4.8 & 8.2 & 0.5 & 3.0 \\
\hline $\mathrm{CI}( \pm)$ & 11.0 & & 1.3 & & 1.6 & & 0.5 & 10.0 & & 1.3 & \\
\hline Ripe fruits $^{\mathrm{e}}$ & 8.0 & 2.9 & 40.2 & 97.6 & 0.5 & 21.7 & 0 & 50.7 & 86.2 & 0.6 & 3.6 \\
\hline $\mathrm{CI}( \pm)$ & 4.3 & & 9.1 & & 0.5 & & & 12.2 & & 0.8 & \\
\hline Pulped fruits ${ }^{\mathrm{f}}$ & 96.3 & 34.3 & $\mathrm{x}$ & $\mathrm{x}$ & 0.5 & 21.7 & 0 & 3.0 & 5.1 & 0.2 & 1.2 \\
\hline $\mathrm{CI}( \pm)$ & 3.8 & & & & 0.5 & & & 3.7 & & 0.3 & \\
\hline Mean & 70.2 & & 14.0 & & 0.6 & & 0.1 & 14.7 & & 4.2 & \\
\hline
\end{tabular}

Pred. dril.: predated by drilling insects, ${ }^{\mathbf{a}} \mathbf{\%} \mathbf{C F}$ : Percentage within the class of fruit, ${ }^{\mathbf{b}} \mathbf{\%} \mathbf{C A}$ : Percentage within class of wildlife activities (\%CA is a proportion of the total \%CF for all classes of fruits). ${ }^{\mathrm{c}}$ Dry pulp: 15 evaluations involving 346 samples and 9,269 fruits. ${ }^{\mathbf{d}}$ Green fruits (unripe): 8 evaluations involving 47 samples and 2,551 fruits. ${ }^{\mathbf{e}}$ Ripe fruits: 17 evaluations involving 251 samples and 11,244 fruits. ${ }^{\mathrm{f}}$ Pulped fruits: 18 evaluations involving 609 samples and 50,065 fruits. CI( $( \pm)$ : Confidence intervals at $95 \%$.

analysis of ripe fruit that fell in the collectors (Appendix). The differences between germination percentage (70.4 and $78.8 \%$ ) are likely related to the environmental conditions observed in the greenhouse (no soil level predation) as well as the characteristics of the seeds used (ripe fruit pulped by wildlife) that exclude attacks of insect drills observed in unripe fruit and cracked and dry fruit recorded in infructescences.

According to our results, the largest bottleneck related to the regeneration of E. edulis is not related to seed destruction before germination, since 322,909 seeds/ha (70.4\%) could germinate, a much higher percentage than the number of seedlings found in class I in 2009 in the study area $(90,876 \pm 31,290$ seedlings/ha). Instead, the highest mortality occurred after seed germination during seedling establishment, where between August 2008 and February 2009 (7 months), $63.2 \pm 7 \%$ of the germinated seeds (seedlings) on the samples arranged on the soil had already died. Other studies corroborated our results and reported large class
I mortalities (between $47.2 \%$ and $55.1 \%$ ) in their first year of life (Conte et al. 2000, Reis and Kageyama 2000, Silva J.Z., unpublished data).

Considering the dynamics of E. edulis natural regeneration, where seedling density is greater closer to reproductive palms, and the limiting effects imposed by density (Silva Matos and Watkinson 1998, Reis and Kageyama 2000), it is likely that only dispersed seeds will be able to replace the current reproductive palms. Of the 70.4 $\%$ seeds that may germinate, these results imply that only $40.8 \%$ are dispersed to conditions that favor establishment (29.9\% from primary dispersal and $10.9 \%$ from secondary dispersal; Figure 1). The remaining $29.6 \%$ are not dispersed and will be subject to new fruiting seasons and seed production from the reproductive palms as well as the limiting conditions imposed by the location itself, such as falling leaves, spathes, and bunches. Studying the dynamics of natural regeneration, Tonetti and Negrelle (2001) observed that the fall of leaves or branches is responsible for annual mortality of 20.6 
$\%$ of E. edulis seedlings. In this sense, we emphasize that local conditions may have a predominant effect on seed quantity that will remain in management systems.

\section{IMPLICATIONS FOR MANAGEMENT AND} CONSERVATION

Our results showed that E. edulis fruit are an important resource for wildlife, which use most of the available resources irrespective of whether production during the year is high or low. These findings make it possible to conclude that sustainable management in natural populations is not possible by simply identifying surpluses, since they are very small. On the other hand, the large variation in the number of fruit produced annually (47\%) leads us to question how wildlife would react to these variations, or even their management, since a) E. edulis may only be a preferred resource and there are other available resources or b) whether there are periods of limited wildlife development due to lack of food caused by low fruitings or even fruit harvesting. To answer these questions, additional studies are needed, mainly aimed at identifying variations caused by years of high and low E. edulis fruit production such as: a) population fluctuations of wildlife, both in size and composition, resulting from oscillating food supply; b) changes in the percentages consumed annually by different species, since such percentages could be a reflection of competition for fruit (Turdus spp. were quite aggressive among themselves) and actions could be directed to species more affected by lack of fruit removal; c) characterize the fruiting phenology of other species in order to demonstrate the importance of E. edulis fruit throughout the year, and other possibilities of food for wildlife.

Contrary to our hypothesis, we could not confirm that the mere identification of E. edulis fruit surpluses would be sufficient to initiate a management program for fruit; however, we can report several observations that might suggest a direction for use and conservation strategies:

a) The volume of ripe fruit produced per hectare can vary considerably between years; in addition, the observed variations were recurrent, and this phenomenon suggests that wildlife is accustomed to some intensity of this oscillation. Thus, harvesting fruit only in years where the production would surpass the annual average may cause minimal impact. The harvest should be limited to the amount that exceeds the annual average. Considering the application of this method on the production estimates (11 fruitings), it would be possible to manage an average of $94 \pm 90 \mathrm{~kg} / \mathrm{ha} /$ year. Based on the prices paid to the extractor for E. edulis fruit per kilogram in 2017 in Santa Catarina State (R\$ 3.50/kg; Companhia Nacional de Abastecimento 2017), it would be possible to obtain an average of R\$329/ha/ year. Although this is a conservative estimate, it represents $\mathrm{R} \$ 3,290$ year on a small property (10 ha) or R \$ 152,327/year in a big area such as the FLONA (463 ha).

b) The quantity of ripe fruits produced/ha/year is a key point in determining the balance between harvesting, feeding of wildlife, dispersal and natural regeneration. Unripe or dry pulp fruits are little used as food by the fauna, and their seeds have reduced germination, contributing little to natural regeneration. In addition, seeds (pulped fruit) are poorly dispersed, limiting the contribution of secondary dispersal.

c) Although many vertebrates are associated with E. edulis (Galetti et al. 2013), the presence of these species does not guarantee they will interact with the fruit. In our study, only 52.5 $\%$ of species interacted with E. edulis and used its fruit and seeds as food. Thus, we believe that floristic composition and faunal interactions also have an important effect on 
the identification of species that depend on $E$. edulis fruiting.

d) Most pulp is consumed from infructescences $(76.5 \%)$, and this fact dictates the direction of future studies, since many currently only include monitoring of activities that occur on the soil that represent the minority of interactions.

e) The most active species in the consumption and dispersal of seeds (T. flavipes) is a migratory bird, and this fact suggests the need for a greater reach for E. edulis conservation strategies. The protection of an E. edulis population also depends on the conservation status of other populations for which T. flavipes migrates or moves along the altitudinal gradient.

f) The composition of wildlife changes during the fruiting months, and this fact indicates that the importance of E. edulis fruit can be quite variable, depending on the needs of each species throughout the fruiting period. In addition, the change in wildlife composition changes dispersal percentages. Therefore, after August, it is likely that fruit management could benefit the natural regeneration of E. edulis because it would reduce the density of seedlings and seeds in the vicinity of the reproductive plants. In this period, dispersal decreases and larger amounts of seeds accumulate around the palms; this phenomenon tends to lead to higher seedling mortality (Silva Matos and Watkinson 1998, Silva Matos et al. 1999, Pizo and Simão 2001).

g) The percentage of dispersed seeds, discounting the destroyed seeds, totaled $40.8 \%, 29.9 \%$ of which resulted from primary dispersal and 10.9 $\%$ from secondary dispersal. It is important to note that most $(97 \%)$ of the dispersed seeds were regurgitated, which favors higher germination percentages, as discussed by Leite et al. (2012). Secondary dispersal is of low quality and is generally related to pulping at distances of less than $1 \mathrm{~m}$ from fruiting palms $(54.2 \%)$ and performed by small rodents (Cricetidae) and by Dasyprocta azarae.

h) The estimate of the percentage of seeds that could germinate in the forest was high (70.4 $\%$ ), and seedling mortality in its first year of life reached $63.2 \%$ in only 7 months. In this sense, local conditions in which natural regeneration is found may be of greater importance to the number of growing seedlings rather than the quantity of seeds that will remain in management systems.

\section{ACKNOWLEDGMENTS}

We would like to thank the team of environmental analysts at the National Forest Ibirama: Flavio Zanchetti, Homero de Oliveira Salazar Filho and Marcela Xavier Machado (Chico Mendes Institute for Biodiversity Conservation - ICMBio). This study was supported by the Conselho Nacional de Desenvolvimento Científico e Tecnológico (CNPq), 309128/2014-5 to Maurício S. Reis, Coordenação de Aperfeiçoamento de Pessoal de Nível Superior (CAPES), postdoctoral fellowship given to Juliano Z. da Silva, and the Fundação de Amparo à Pesquisa e Inovação do Estado de Santa Catarina (FAPESC) - PRONEX/2780/2012-4.

\section{AUTHOR CONTRIBUTIONS}

J.Z.S. and M.S.R. contributed to the design of the research. J.Z.S. performed the measurements, processed the experimental data, drafted the manuscript and designed/produced the figures. M.S.R was involved in supervised the Work. All authors discussed the results and commented on the manuscript.

\section{REFERENCES}

BARROSO RM, REIS A AND HANAZAKI N. 2010. Etnoecologia e etnobotânica da palmeira juçara (Euterpe 
edulis Martius) em comunidades quilombolas do Vale do Ribeira, São Paulo. Acta Bot Bras 24: 518-528.

BERNAL R, TORRES C, GARCÍA N, ISAZA C, NAVARRO J, VALLEJO MI, GALEANO G AND BALSLEV H. 2011. Palm management in South America. Bot Ver 77: 607-646.

BICKNELL J AND PERES CA. 2010. Vertebrate population responses to reduced-impact logging in a neotropical forest. For Ecol Manag 259: 2267-2275.

CALVI GP AND PIÑA-RODRIGUES FCM. 2005. Fenologia e produção de sementes de Euterpe edulis - MART em trecho de floresta de altitude no município de Miguel Pereira-RJ. Rev Uni Rur 25(1): 33-40.

CAMPOS RC, STEINER J AND ZILLIKENS A. 2012. Bird and mammal frugivores of Euterpe edulis at Santa Catarina island monitored by camera traps. Stud Neotrop Fauna E 47(2): 1-6, 2012.

CASTRO ER, CÔRTES MC, NAVARRO L, GALETTI M AND MORELLATO LP. 2012. Temporal variation in the abundance of two species of thrushes in relation to fruiting phenology in the Atlantic rainforest. Emu 112(2): 137-148.

CAZASSA RS, PEREIRA A, SILVA ET AND SOUZA RF. 2016. Aves como potenciais dispersoras de sementes de Euterpe edulis (arecaceae) em um fragmento de mata atlântica em Piedade de Caratinga, Minas Gerais. Rev Cienc 7(1): 95-109.

CERISOLA CM, ANTUNES AZ AND PORT-CARVALHO M. 2007. Consumo de frutos de Euterpe edulis Martius (arecaceae) por vertebrados no parque estadual Alberto Löfgren, São Paulo, sudeste do Brasil. IF Sér Reg 31: 167171.

COMPANHIA NACIONAL DE ABASTECIMENTO, 2017. Boletim da Sociobiodiversidade. Brasília: Conab 1(2): $1-61$.

CONTE R, REIS MS, GUERRA MP, NODARI RO AND FANTINI AC. 2000. Manejo sustentado do palmiteiro (Euterpe edulis M.) na pequena propriedade catarinense. Agrop Cat 13: 38-42.

CONTE R, NODARI RO, VENCOVSKY R AND REIS MS. 2003. Genetic diversity and recruitment of the tropical palm, Euterpe edulis Mart., in a natural population from the Brazilian Atlantic Forest. Heredity 91: 401-406.

FADINI RF AND MARCO-JR P. 2004. Interações entre aves frugívoras e plantas em um fragmento de mata atlântica de Minas Gerais. Ararajuba 12(2): 97-103.

FADINI RF, FLEURY M, DONATTI C AND GALETTI M. 2009. Effects of frugivore impoverishment and seed predators on the recruitment of a keystone palm. Acta Oecol 35: 188-196.

FANTINI AC AND GURIES RP. 2007. Forest structure and productivity of palmiteiro (Euterpe edulis Martius) in the Brazilian Mata Atlântica. For Ecol Manag 242: 185-194.

FAVRETO R, MELLO RSP AND BAPTISTA LRM. 2010. Growth of Euterpe edulis Mart. (Arecaceae) under forest and agroforestry in southern Brazil. Agroforest Syst 80: 303-313.

FLEIG FD AND RIGO SM. 1998. Influence of palm Euterpe edulis Mart. fruit size on seeds germination and seedling growth. Cienc Florest 8(1): 35-41.

FRECKLETON RP, MATOS DMS, BOVI MLA AND WATKINSON AR. 2003. Predicting the impacts of harvesting using structured population models: the importance of density-dependence and timing of harvest for a tropical palm tree. J Appl Ecol 40: 846-858.

FREDERICKSEN TS, RUMIZ D, BRAVO MJJ AND ABACAY RA. 1999. Harvesting free-standing fig trees for timber in Bolivia: potential implications for forest management. For Ecol Manag 116: 151-161.

GALETTI M ET AL. 2013. Functional extinction of birds drives rapid evolutionary changes in seed size. Science 340: 1086-1090.

GALETTI M AND ALEIXO A. 1998. Effects of palm heart harvesting on avian frugivores in the Atlantic rain forest of Brazil. J Appl Ecol 35: 286-293.

GALETTI M AND CHIVERS DJ. 1995. Palm harvest threatens Brazil's best protected area of Atlantic Forest. Oryx 29: 225-226.

GALETTI M, KEUROGHLIAN A, HANADA L AND MORATO MI. 2001. Frugivory and seed dispersal by the Lowland Tapir (Tapirus terrestris) in Southeast Brazil. Biotropica 33: 723-726.

GALETTI M, LAPS RR AND PIZO MA. 2000. Frugivory by toucans (Ramphastidae) at two altitudes in Atlantic rain forest of Brazil. Biotropica 32: 842-850.

GALETTI M, ZIPPARRO VB AND MORELLATO LPC. 1999. Fruiting phenology and frugivory on the palm Euterpe edulis in a lowland Atlantic Forest of Brazil. Ecotropica 5: 115-122.

GENINI J, GALETTI M AND MORELLATO LPC. 2009. Fruiting phenology of palms and trees in an Atlantic rainforest land-bridge island. Flora 204: 131-145.

GODOY RA AND BAWA K. 1993. The economic value and sustainable harvest of plants and animals from the tropical forest: assumptions, hypotheses and methods. Econ Bot 47: 215-219.

HENDERSON A. 2000. The genus Euterpe edulis in Brazil. In: Reis A and Reis MS (Eds), Euterpe edulis Martius - Biologia, conservação e manejo sustentado, Itajaí: Herbário Barbosa Rodrigues, Itajaí-SC, Brasil, p. 1-22.

JUSTEN JGK, MULLER JJV AND TORESAN L. 2012. Levantamento Socioambiental. In: Vibrans AC, Sevegnani L, Gasper AL and Lingner DV (Eds), Diversidade e Conservação dos Remanescentes Florestais, Blumenau: Edifurb, Blumenau-SC, Brasil, p. 243-262.

KINNAIRD MF. 1992. Competition for a forest palm: use of Phoenix reclinata by humam and nonhuman primates. Conserv Biol 6: 101-107. 
KLEIN RM, PASTORE U AND COURA-NETO AB. 1986. Vegetação. In: Gabinete de Planejamento e Coordenação Geral (Ed), Atlas de Santa Catarina, Florianópolis: Brasil, p. 35-36.

LAMBERT FR AND MARSHALL AG. 1991. Keystone characteristics of bird-dispersed Ficus in a Malaysian lowland rain forest. J Ecol 79: 793-809.

LEITE AB, BRANCALION PHS, GUEVARA R AND GALETTI M. 2012. Differential seed germination of a keystone palm (Euterpe edulis) dispersed by avian frugivores. J Trop Ecol 28: 615-618.

MANTOVANI A AND MORELLATO P. 2000. Fenologia da floração, frutificação, mudança foliar e aspectos da biologia floral. In: Reis A and Reis MS (Eds), Euterpe edulis Martius - Biologia, conservação e manejo sustentado, Itajaí: Herbário Barbosa Rodrigues, Itajaí-SC, Brasil, p. 23-38.

MIKICH SB. 2002. A dieta frugívora de Penelope superciliaris (Cracidae) em remanescentes de floresta estacional semidecidual no centro-oeste do Paraná, Brasil e sua relação com Euterpe edulis (Arecaceae). Ararajuba 10: 207-217.

MOEGENBURG SM AND LEVEY DJ. 2002. Prospects for conserving biodiversity in Amazonian extractive reserves. Ecol Lett 5: 320-324.

MOEGENBURG SM AND LEVEY DJ. 2003. Do frugivores respond to fruit harvest? An experimental study of shortterm responses. Ecology 84: 2600-2612.

OMOTE T, ANTUNES AZ AND MATSUKUMA CK. 2014. Comparative fruit phenology and frugivory between the native palm Euterpe edulis Mart. and the exotic palm Phoenix Roebelenii O'brien (Arecaceae) in southeastern Brazil. Rev Inst Flor 26(2): 169-181.

PALUDO GF, SILVA JZ AND REIS MS. 2012. Estimativas de Produção de Frutos de Palmiteiro (Euterpe edulis Mart.) a partir da Densidade de Indivíduos. Biod Bras 2(2): 92-102.

PANDEY AK AND SHACKLETON CM. 2012. The effect of harvesting approaches on fruit yield, embelin concentration and regrowth dynamics of the forest shrub, Embelia tsjeriam-cottam, in central India. For Ecol Manag 266: 180-186.

PERES CA. 1994. Composition, density, and fruiting phenology of arborescent palms in an Amazonian terra firme forest. Biotropica 26: 285-294.

PINARD MA AND PUTZ FE. 1992. Population matrix models and palm resource management. Bull. Inst fr études andines 21: 637-649.

PIZO MA AND SIMÃO I. 2001. Seed deposition patterns and the survival of seeds and seedlings of the palm Euterpe edulis. Acta Oecol 22: 229-233.

PIZO MA, SILVA WR, GALETTI M AND LAPS RR. 2002. Frugivory in cotingas of the Atlantic forest of southeast Brazil. Ararajuba 10: 177-185.
PORTELA RCQ, BRUNA EM AND SANTOS FAM. 2010. Demography of palm species in Brazil's Atlantic forest: a comparison of harvested and unharvested species using matrix models. Biodivers Conserv 19: 2389-2403.

R DEVELOPMENT CORE TEAM. 2015. R: A language and environment for statistical computing. R Foundation for Statistical Computing, Vienna, Austria. http://www.Rproject.org. Vienna, Austria. Available from http://www.rproject.org/.

REIS A AND REIS MS. 2000. Euterpe edulis Martius - Biologia, conservação e manejo sustentado, Itajaí: Herbário Barbosa Rodrigues, Itajaí SC, Brasil, 335 p.

REIS A AND KAGEYAMA PY. 2000. Dispersão de sementes do palmiteiro (Euterpe. edulis Martius - Palmae). In: Reis A and Reis MS (Eds.), Euterpe edulis Martius - Biologia, conservação e manejo sustentado, Itajaí: Herbário Barbosa Rodrigues, Itajaí-SC, Brasil, p. 60-92.

REIS MS. 1996. Dinâmica da movimentação dos alelos: subsídios para a conservação e manejo de populações naturais em plantas. Rev Bras Genet 19: 37-47.

REIS MS, FANTINI AC, NODARI RO, GUERRA MP, REIS A AND MANTOVANI A. 2000. Management and conservation of natural populations in Atlantic rain forest: the case study of palm heart (Euterpe edulis Martius). Biotropica 32: 894-902.

SEOANE CES, KAGEYAMA PY, RIBEIRO A, MATIAS R, REIS MS, BAWA K AND SEBBENN AM. 2005. Efeitos da fragmentação florestal sobre a imigração de sementes e a estrutura genética temporal de populações de Euterpe edulis Mart. Rev Inst Flor 17: 25-43.

SICK H. 1997. Ornitologia Brasileira. Rio de Janeiro: Ed. Nova Fronteira, 912 p.

SILVA AR, SILVEIRA RR, AUMOND A, SILVEIRA AB AND CADEMARTORI CV. 2017. Frugivoria e dispersão de sementes de Euterpe edulis Mart. (Arecacea) por mamíferos e aves silvestres na Mata Atlântica do Sul do Brasil. Rev Bras Zoociências 18(3): 138-158.

SILVA JZ AND REIS MS. 2010. Effects of Different Simulated Management Intensities on The Genetic Diversity of a Heart-of-palm Tree Natural Population (Euterpe edulis Martius). Silvae Genet 59: 201-210.

SILVA JZ AND REIS MS. 2018. Reproductive phenology and production of fruits in Euterpe edulis (Martius). Cienc Florest 28(1): 295-309.

SILVA MATOS DM AND WATKINSON AR. 1998. The fecundity, seed, and seedling ecology of the edible palm Euterpe edulis in Southeastern Brazil. Biotropica 30: 595603.

SILVA MATOS DM, FRECKLETON RP AND WATKINSON AR. 1999. The role of density dependence in the population dynamics of a tropical palm. Ecology 80: 2635-2650.

STAGGEMEIER VG, CAZETTA E AND MORELLATO LPC. 2017. Hyperdominance in fruit production in the 
Brazilian Atlantic rain forest: the functional role of plants in sustaining frugivores. Biotropica 49(1): 71-82.

TERBORGH J. 1986. Keystone plant resources in the tropical forest. In: Soulé ME (Ed), Conservation biology, the science of scarcity and diversity, Sinauer Associates, Sunderland. p. 330-344.

TONETTI EL AND NEGRELLE RRB. 2001. Dinâmica do banco de plântulas de palmito em ambiente natural. Sci agraria 2: 79-85.

TREVISAN ACD, FANTINI AC, SCHMITT-FILHO AL AND FARLEY J. 2015. Market for Amazonian açaí (Euterpe oleraceae) stimulates pulp production from Atlantic Forest juçara berries (Euterpe edulis). Agroecol. Sustain. Food Syst 39(7): 762-781.

WETERINGS MJA, WETERINGS-SCHONCK SM, VESTER HFM AND CALMÉ S. 2008. Senescence of Manilkara zapota trees and implications for large frugivorous birds in the Southern Yucatan Peninsula, Mexico. For Ecol Manag 256: 1604-1611.

\section{SUPPLEMENTARY MATERIAL}

Table SI - Wildlife recorded in Ibirama National Forest (Management Plan ${ }^{\mathrm{A}}$ and this study) associated with the consumption of Euterpe edulis fruit and pulp of by Galetti et al. (2013), Campos et al. (2012), and this study.

Figure S1 - a) Model of fruit collectors installed in the study area. b) and c) Using camera traps to monitor infructescences. d) Samples that contained fruit or seeds arranged on the soil. Drawing of Euterpe edulis adapted from Henderson (2000).

Figure S2 - Wildlife recorded interacting with Euterpe edulis fruit and seeds in Ibirama National Forest. * Image by Homero O. Salazar; other images by Juliano Z. Silva.

\section{APPENDIX}

DETAILS OF THE CONSUMPTION OF FRUIT AND THE PERCENTAGE OF SEED AVAILABLE FOR NATURAL REGENERATION FROM WILDLIFE ACTIVITIES OCCURRING AT GROUND LEVEL.

Seeds available for the natural regeneration process basically have as origin the following: $19.8 \%$ intact fruit, $25 \%$ pulped fruits, $2.8 \%$ scratched fruit and $39.4 \%$ dispersed fruits $=87 \%$ (Table III; Figure 1). However, these percentages suffer even greater reductions owing to the ecological processes occurring on the soil where seeds are subjected to pulping, predation, transport and rotting caused by microorganisms.

Of the first $25 \%$ of fruit reaching the ground as pulped, $96.3 \%$ will remain intact, $3 \%$ will be transported and $0.7 \%$ will be destroyed by predation and rot (Table IV; Figure 1). However, for $3 \%$ of seeds that are transported, the motivation is the endosperm, since it is pulped. Therefore, the chance of predation is high. For this reason, these seeds are considered destroyed, reducing the percentage from 25 to $24.1 \%$. However, these fruits are also subject to fungal contamination, and unlike the value obtained for intact fruits, this value has yet to be corrected. To do this, we used the average percentage of fruits with fungal attacks found in each collector during the period in which the ripe fruit was subjected to transport and pulping, where the value found was $21 \%$. This correction resulted in $19 \%$ participation in the regeneration process (Figure 1).

Ripe fruit reaching the ground was composed of $19.8 \%$ fallen intact fruit and $2.8 \%$ scratched fruit $(19.8+2.8=22.6 \%)$. From Table IV and Figure 1, it can be seen that $40.2 \%$ will be pulped, $8 \%$ will remain intact, $50.7 \%$ will be transported and $1.1 \%$ will be lost through decay and predation. The $40.2 \%$ that will be pulped on the soil begins to behave like pulped fruits that reach the ground, i.e., $96.3 \%$ contribute to regeneration and $3.7 \%$ will be destroyed. Thus, of the $40.2 \%$ pulped fruits, only $38.7 \%$ of the $22.6 \%$ of ripe fruits that reach the forest floor contribute to the regeneration process $(8.75 \%)$. The $50.7 \%$ of seeds transported from the ground that contain pulp, as suggested by the data in Table IV, will be pulped with preference. Nevertheless, as shown by the data in Table IV, for ripe fruit, $0.5 \%$ will be predated, $0.6 \%$ will rot, and the remaining $98.9 \%$ will be pulped (11.33 $\%$ ). However, after being pulped, they will assume the behavior observed for pulped fruit on the soil, where, again, $96.3 \%$ will contribute to regeneration $(10.91 \%)$ and $3.7 \%$ will be destroyed $(0.42 \%)$. 
In this regard, while $50.7 \%$ of fruit will be transported from the ground, only $48.8 \%$ will contribute to the regeneration process. Thus, of the $22.6 \%$ of ripe fruits that arrive intact on the forest floor, $95.5 \%$ of the seeds $(8+38.7+48.8)$ will contribute to the regeneration process, i.e., $21.5 \%$ $(1.8+8.8+10.9-$ Figure 1$)$.

Given that the main attraction associated with primary dispersal is the pulp, $39.4 \%$ of the transported fruit in primary dispersal is likely to be pulped. However, $0.5 \%$ predation was observed within collectors, which may also occur with transported fruit. Thus, the percentage of fruits transported that can germinate will be reduced to $39.2 \%$. These fruits will also be subject to fungal attack, requiring a correction in value. In order to do this, the average percentage of fruit infected with fungus was found for each sample in each collector during the period in which ripe fruit was subjected to transport. The value was $21 \%$, which reduces the value of 39.2 to $31 \%$. As they reach the ground, pulped fruit will still suffer from $0.5 \%$ predation, $0.2 \%$ from decay and $3 \%$ from transport, which is motivated by the endosperm of the seed, most likely destroying them. Computing these losses to $3.7 \%$, the percentage of transported fruits able to germinate will be $29.9 \%$ (Figure 1).

Including all losses/reductions, $70.4 \%$ $(19+21.5+29.9)$ represents total fruit destined to become germinating seeds (Figure 1). The destruction of $16.6 \%$ occurred mainly on the soil and during dispersal, and of this total, 13.3 $\%$ results from fungal attacks and $3.3 \%$ from predation and rot. These results are summarized in Figure 1, which shows $70.4 \%$ of seeds capable of germination and $29.6 \%$ of seeds destroyed by fungal attach $(20.2 \%)$, insect larvae (1.9\%), predation and microorganisms $(3.8 \%)$ and dry and cracked fruits $(3.7 \%)$. 